\title{
PERANCANGAN MESIN PERONTOK JAGUNG DENGAN KAPASITAS PRODUKSI 300 KG/JAM
}

\author{
Basori, Marsudi dan Bima Rizky Saputra \\ Teknik Mesin, Fakultas Teknik dan Sains, Universitas Nasional \\ e-mail : ory_banjarn@yahoo.com
}

\begin{abstract}
ABSTRAK
Perontokan jagung pada industri rumah tangga atau industri kecil sebagian besar dilakukan dengan cara tradisional. Hal tersebut memerlukan banyak tenaga, waktu dan laju produksinya rendah, sehingga metode perontok jagung secara tradisional tidak efisien. Menyikapi permasalahan tersebut di atas, pada penelitian tugas akhir ini telah dilakukan perancangan mesin perontok jagung dengan kapasitas produksi $300 \mathrm{~kg} / \mathrm{jam}$. Hasil perancangan didapatkan data spesifikasi setiap komponen mesin antara lain : panjang silinder perontok $900 \mathrm{~mm}$ dan diameter $430 \mathrm{~mm}$, pully penggerak berdiameter $75 \mathrm{~mm}$ dengan putaran motor (n1) sebesar 1500 rpm, sedangkan pully yang digerakkan berdiameter 357,1 mm dengan putaran motor (n2) sebesar $315 \mathrm{rpm}$. Vbelt tipe A-5 dengan panjang $2135 \mathrm{~mm}$ dan kecepatan liniernya $6 \mathrm{~m} / \mathrm{s}$. Bantalan yang digunakkan adalah bantalan gelinding yang mempunyai luas permukaan 961,6 mm2 dengan diameter dalam $35 \mathrm{~mm}$ dan diameter luar $45 \mathrm{~mm}$, tegangan yang diijinkan 58,90 N/mm2 > tegangan yang terjadi 0,689 N/mm2. Diameter poros 8,34 mm dengan tegangan geser 0,36 N/mm2 dan tegangan geser yang diijinkan sebesar 56,90 N/mm2. Panjang pasak 53,42 mm dan lebar $9 \mathrm{~mm}$. Daya motor yang dibutuhkan untuk menggerakkan silinder sebagai perontok 164,3 W, sedangkan daya terpasang sebesar 213,6 W. Secara keseluruhan data-data hasil perancangan dinyatakan memenuhi syarat untuk dirancang bangun.
\end{abstract}

Kata kunci: Mesin, Perontok, Jagung

\section{PENDAHULUAN}

Pertumbuhan jagung di Indonesia telah menjangkau ke daerah-daerah seperti di Lampung, Gorontalo, Sulawesi Tenggara, Dompu, Bima, Sumbawa, Jawa Timur, dan Sulawesi Selatan, khususnya daerah Sumbawa yang mana jagung merupakan sumber karbohidrat yang kedua setelah padi. Selain sebagai bahan makan pokok masyarakat, jagung dapat diolah menjadi produk industri makanan yang variatif, di antaranya jagung dapat diolah menjadi makanan kecil, dan lain-lain. Jagung juga dapat diproses menjadi bahan campuran pakan ternak seperti pada unggas.

Perontokan jagung mudah dilakukan bila jagung dalam keadaan kering, sebab dalam keadaan demikian jagung mudah terlepas dari bonggolnya dan selain itu pula kerusakan biji jagung dapat diperkecil. Perontokan jagung pada industri rumah tangga atau industri kecil sebagian besar dilakukan dengan cara tradisional. Hal tersebut memerlukan banyak tenaga, waktu dan laju produksinya rendah, sehingga metode perontok jagung secara tradisional tidak efisien.

Dengan memperhatikan kondisi di atas, maka perlu dilakukan upaya untuk merubah cara penanganan pasca panen jagung menjadi lebih cepat dan efisien. Salah satu metode yang dapat mengatasi permasalahan di atas yaitu perlu adanya perancangan mesin berteknologi tepat guna yang mampu meningkatkan laju produksi dan harga jual mesin yang dapat terjangkau oleh masyarakat petani jagung. Dengan meningkatnya laju produksi pasca panen jagung maka penghasilan para petani jagung tentunya bertambah, sehingga berdampak pula pada kesejahteraan.

\section{MESIN PERONTOK JAGUNG}

\subsection{Deskripsi Mesin Perontok Jagung}

Mesin perontok jagung merupakan mesin yang berfungsi sebagai alat untuk memisahkan biji jagung dari bonggolnya. Sumber tenaga yang digunakan adalah motor listrik, sedangkan sistem penyaluran tenaga menggunakan sistem transmisi pully.

Pada dasarnya prinsip kerja mesin perontok jagung merupakan proses perontokan jagung yang terjadi akibat perputaran diantara bongkol jagung dengan silinder perontok yang berkedudukan secara dinamis dengan sisi ruang perontok berupa baut yang difungsikan sebagai mata perontok. Gesekan yang timbul disebabkan oleh putaran silinder perontok dengan sisi statis. Putaran diperoleh dari motor listrik yang disalurkan melalui sistem transmisi pully. 


\subsection{Gambar Komponen}

a. Silinder Perontok

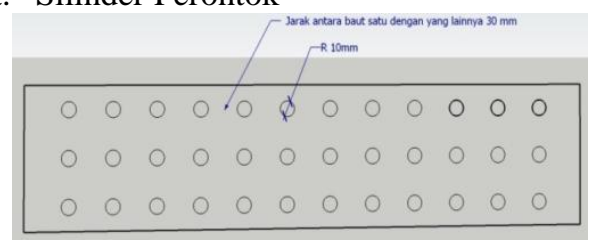

Gambar 2.1 Silinder perontok tampak depan

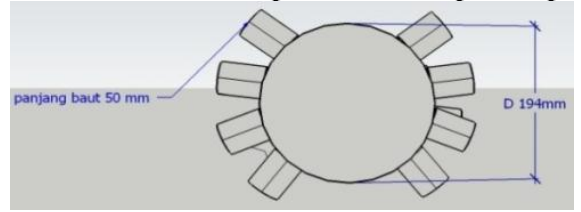

Gambar 2.2 Silinder perontok tampak kiri

b. Tabung Perontok

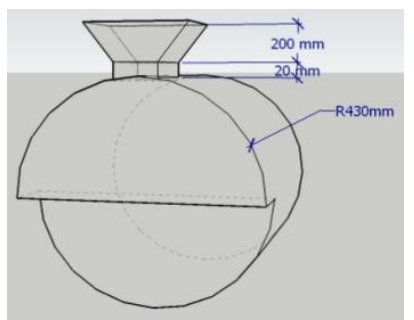

Gambar 2.3 Tabung perontok tampak depan

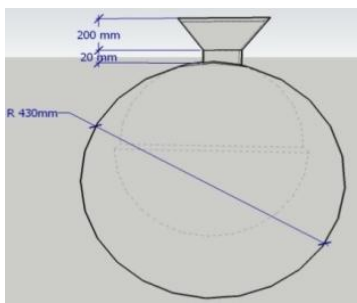

Gambar 2.4 Tabung perontok tampak belakang

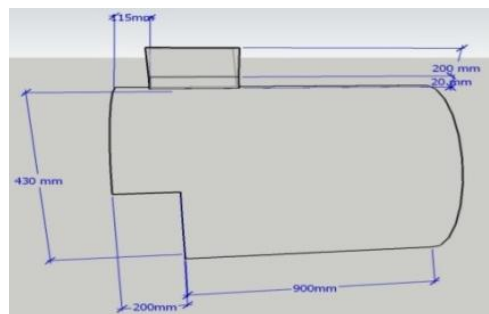

Gambar 2.5 Tabung perontok tampak kanan

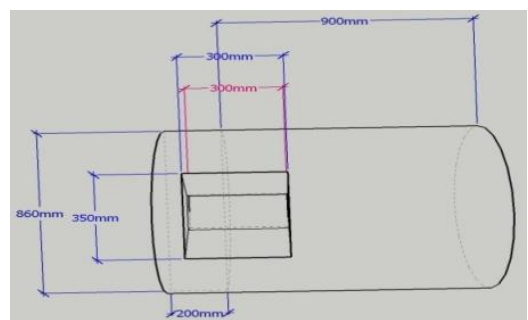

Gambar 2.6 Tabung perontok tampak atas

c. Dudukan mesin

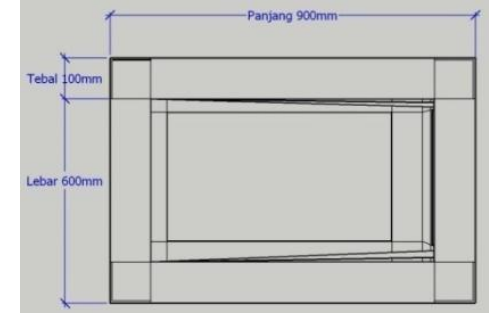

Gambar 2.7 Dudukan mesin tampak atas

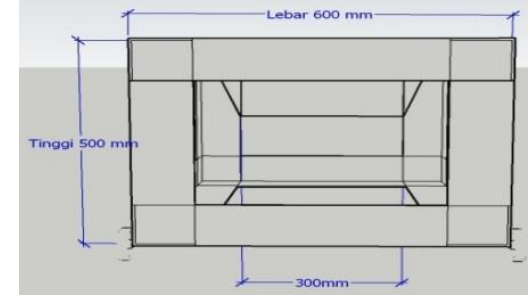

Gambar 2.8 Dudukan mesin tampak kiri

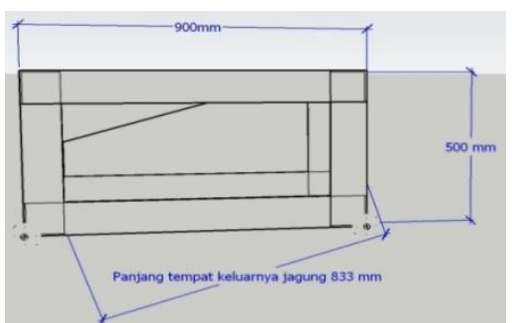

Gambar 2.9 Dudukan mesin tampak belakang

\subsection{Desain Alat}

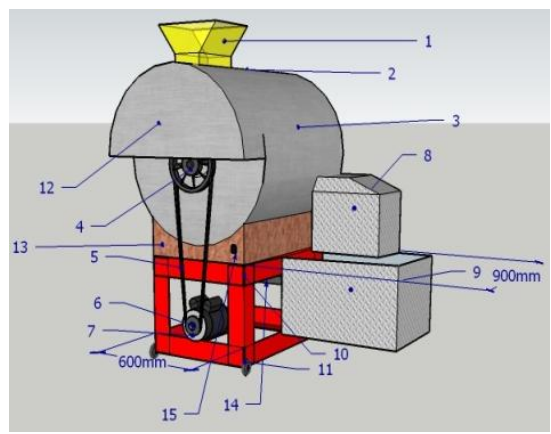

Gambar 2.10. Desain Mesin Perontok

\section{No Keterangan}

1. Tempat masuknya jagung

2. Silinder perontok

3. Tabung

4. Pully yang digerakkan

5. Sabuk-V

6. Pully penggerak

7. Motor listrik

8. Tempat keluarnya bonggol jagung

\section{Keterangan}

9. Tempat pembuangan perontokan jagung

10. Kerangka mesin

11. Roda

12. Penutup pully yang digerakkan

13. Tempat penahan tabung silinder

14. Tempat saringan

15. Tombol power 
Adapun proses perakitan mesin perontok jagung sebagai berikut :

1) Membuat kerangka mesin (10).

2) Memasang roda (11).

3) Membuat dan memasang tempat penahan tabung silinder (13).

4) Memasang tombol power (15).

5) Membuat dan memasang tempat masuknya biji bonggol jagung (1) beserta tempat untuk menahan silinder perontok (3).

6) Membuat dan memasang saringan inti dengan pelat lubang sebagai inti saringan (14) dan saringan pembuangan bonggol jagung (8).

7) Membuat dudukan dan memasang silinder perontok (2), sabuk-v (5), pully penggerak (6) dan pully yang digerakkan (4).

8) Memasang motor listrik (7)

9) Membuat dan memasang tutup pengaman pully yang digerakkan (12).

10) Memasang pembuangan hasil perontokan jagung (9).

\subsection{Cara Kerja Alat Mesin Perontok Jagung}

Adapun cara kerja alat mesin perontok jagung sebagai berikut :

a. Jagung yang sudah dikeringkan ditempatkan pada wadah saluran masuk (corong masuk) (1).

b. Tombol power ditekan (15), maka motor akan berputar sehingga secara otomatis akan memutar silinder perontok (2).

c. Jagung akan tertarik secara otomatis karena gerutan yang telah dibuat pada masingmasing silinder. Maka biji jagung dan bonggolnya yang telah rontok akan keluar melalui saringan inti (14) sedangkan bonggol jagung keluar melalui saringan pembuangan (8).

\subsection{Komponen Utama Mesin Perontok Jagung}

\subsubsection{Silinder Perontok}

Silinder perontok merupakan bagian yang paling berperan dalam mesin perontok jagung. Oleh karena itu perancangan dari silinder perontok ini harus dilakukan dengan baik sehingga didapatkan hasil yang maksimal dari mesin perontok jagung. Pemilihan bentuk dari silinder perontok didasarkan pada hasil studi lapangan, dimana silinder perontok yang efektif untuk merontokkan jagung adalah berbentuk silinder dengan mata perontok berupa baut-baut panjang yang tersusun rapi pada suatu plat besi. Baut-baut panjang tersebut disusun pada sekeliling plat silinder. Persamaan-persamaan yang digunakan dalam perencanaan silinder perontok adalah :

$$
\text { a. Momen inersia }
$$
Dimana :
I : Momen inersia $\left(\mathrm{Nmm}^{2}\right)$
$\mathrm{m}$ : Massa total $(\mathrm{N})$
$\mathrm{r} \quad$ : Jari-jari silinder ( $\mathrm{mm})$

b. Momen puntir

$\mathrm{T}=\frac{\left(\mathrm{F}_{1}-\mathrm{F}_{2}\right) \times \mathrm{Dp}}{2}$

Dimana :

F1 : Gaya tarik sabuk (N)

$\mathrm{T}$ : Momen puntir (Nmm)

F2 : Gaya sisi kendor sabuk (N)

$\mathrm{Dp}$ : Diameter pully yang digerakkan $(\mathrm{mm})$

\subsubsection{Pully}

Pully pada mesin berfungsi sebagai penerus putaran dan daya dari motor melalui sabuk ke poros dan untuk menyimpan tenaga agar silinder atau poros tetap berputar bila mendapat beban. Pully biasanya terbuat dari besi tuang, baja tuang, kayu dan kertas. Pully yang terbuat dari besi mempunyai gaya gesek dan karakteristik penggunaan yang baik. Konstruksi pully dapat dilihat pada gambar 2.11.

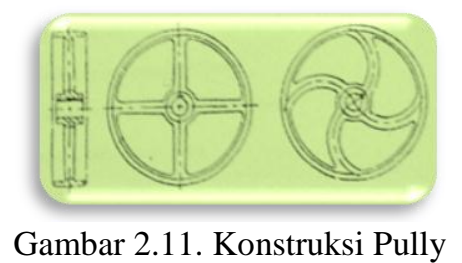

Rumus-rumus yang digunakan untuk perancangan pully:

a. Diameter pully yang digerakkan (Dp)

$$
\frac{\mathrm{n}_{2}}{\mathrm{n}_{1}}=\frac{\mathrm{d}_{\mathrm{p}}}{\mathrm{D}_{\mathrm{p}}}
$$

Dimana :

$\mathrm{n}_{1}$ : Putaran pully penggerak (rpm)

$\mathrm{n}_{2}$ : Putaran pully yang digerakkan (rpm)

$\mathrm{dp}$ : Diameter pully penggerak $(\mathrm{mm})$

$\mathrm{Dp}$ : Diameter pully yang digerakkan $(\mathrm{mm})$

b. Sudut Kontak

$\theta=180^{\circ}-\frac{57^{\circ}(\mathrm{Dp}-\mathrm{dp})}{\mathrm{C}}$

Dimana :

$\theta \quad$ : Sudut kontak $\left({ }^{\circ}\right)$

$\mathrm{dp}$ : Diameter pully penggerak $(\mathrm{mm})$

$\mathrm{Dp}$ : Diameter pully yang digerakkan $(\mathrm{mm})$

C : Jarak sumbu poros (mm)

\subsubsection{V-belt}

V-belt dipasang pada pully beralur diantara 2 poros yang jaraknya mencapai 5 meter dengan perbandingan 1:1 sampai 7:1 V-belt terbuat dari 
karet yang mempunyai penampang trapesium. Sabuk ini dililitkan pada pully yang berbentuk V. Bagian sabuk yang membelit pada pully mengalami lengkungan sehingga lebar bagian dalamnya akan bertambah besar. Hal ini merupakan salah satu keunggulan sabuk-V dibandingkan sabuk rata, transmisi roda gigi atau rantai. V-belt bekerja lebih halus dan nyaris tidak bersuara.

Untuk mentransmisikan daya dapat dipakai beberapa V-belt yang dipasang berdampingan. Transmisi ini dapat digunakan pada kompresor, mobil (penggerak kipas), gerigi mesin, mesin jahit, mesin penggiling dan lain-lain. Kontruksi V-belt dapat dilihat pada gambar 2.12. beserta ukuran penampangnya dapat dilihat pada gambar 2.13.

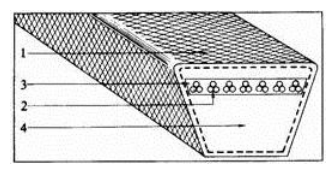

Keterangan :

1. Terpal

2. Bagian penarik

3. Karet pembungkus

4. Bantal karet

Gambar 2.12 Konstruksi V-belt

Sedangkan untuk ukuran V-belt yang umum digunakan dapat dilihat seperti pada gambar 2.13.

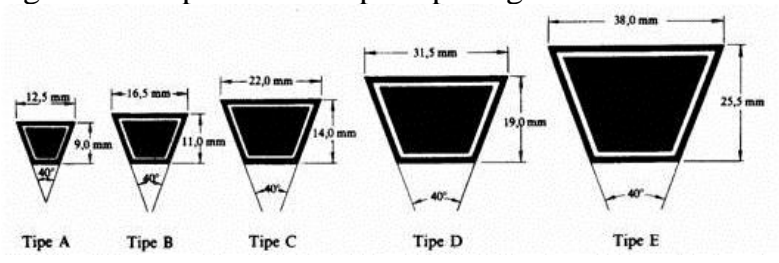

Gambar 2.13 Ukuran Penampang V-belt

Persamaan-persamaan yang digunakan pada perencanan sabuk-V yaitu :

a. Panjang keliling sabuk dari pully penggerak ke pully yang digerakkan

$$
\mathrm{L}=2 . \mathrm{C}+\frac{\pi}{2}(\mathrm{Dp}+\mathrm{dp})+\frac{1}{4 . \mathrm{C}}(\mathrm{Dp}-\mathrm{dp})^{2}(2.5)
$$

Dimana :

L : Panjang keliling sabuk (mm)

C : Jarak sumbu poros ( $\mathrm{mm}$ )

$\mathrm{dp}$ : Diameter pully penggerak (mm)

$\mathrm{Dp}$ : Diameter pully yang digerakkan $(\mathrm{mm})$

b. Sudut kontak sabuk

$$
\theta=\frac{\frac{D p-d p}{2}}{C}
$$

Dimana :

$\theta$ : sudut kontak sabuk (rad)

$\mathrm{dp}$ : diameter puli penggerak ( $\mathrm{mm}$ )

$\mathrm{Dp}$ : diameter puli yang digerakkan ( $\mathrm{mm})$

$\mathrm{C}$ : jarak sumbu poros (mm) c. Kecepatan keliling

$$
\begin{aligned}
\mathrm{v}= & \frac{\pi \times \mathrm{dp} \times \mathrm{n}}{60 \times 1000} \\
& \text { Dimana : } \\
& \mathrm{v}: \text { kecepatan keliling }(\mathrm{m} / \mathrm{s}) \\
& \mathrm{dp}: \text { diameter puli penggerak }(\mathrm{mm}) \\
& \mathrm{n}: \text { putaran motor }(\mathrm{rpm})
\end{aligned}
$$

d. Gaya tarik sabuk $\left(\mathrm{F}_{1}\right)$

$$
\begin{aligned}
& \mathrm{F}_{1}=\mathrm{f} \mathrm{x} \text { a } \\
& \quad \text { Dimana : } \\
& \mathrm{F}_{1}: \text { gaya tarik sabuk }(\mathrm{N}) \\
& \mathrm{f}: \text { tegangan pada sabuk }\left(\mathrm{N} / \mathrm{cm}^{2}\right) \\
& \text { a : luas permukaan sabuk }\left(\mathrm{mm}^{2}\right)
\end{aligned}
$$

e. Gaya sisi kendor sabuk $\left(\mathrm{F}_{2}\right)$

$$
\begin{aligned}
& 2,3 \log \frac{\mathrm{F}_{1}}{\mathrm{~F} 2}=\mu \theta \\
& \text { Dimana }: \\
& \theta: \text { sudut kontak pully } \\
& \mu: \text { koefisien gesek }=0,35
\end{aligned}
$$

\subsubsection{Mur dan Baut}

Mur dan baut merupakan alat pengikat yang sangat penting pada mesin. Fungsi mur dan baut adalah menyambung dua buah logam dan plat menjadi satu.

Mur dan baut biasanya mempunyai ulir dengan penampang ulir segitiga dan trapesium. Ulir baut biasanya putarannya searah jarum jam. Apabila untuk mengencangkan mur dan baut diputar ke kanan dan untuk melepas diputar ke kiri. Baut umumnya mempunyai kepala segi empat atau segi enam untuk memasang atau membuka baut menggunakan kunci momen.

\subsubsection{Pisau Perontok}

Pada perancangan silinder perontok, baut digunakan sebagai mata perontok. Hal ini dimaksudkan untuk memudahkan proses pengerjaan dari silinder perontok.

Baut yang digunakan adalah baut M12 x 1,75 dengan panjang $50 \mathrm{~mm}$ terbuat dari baja SC 37 (JIS 65101), yang mempunyai kekuatan tarik 37 $\mathrm{kg} / \mathrm{mm}^{2}$ atau $362,6 \mathrm{~N} / \mathrm{mm}^{2}$.

\subsubsection{Poros}

Poros merupakan salah satu bagian yang terpenting dari setiap mesin. Hampir semua mesin meneruskan tenaga bersama-sama dengan putaran. Peranan utama dalam transmisi seperti ini dipegang oleh poros.

Pada perencanaan poros silinder perontok,rumus-rumus yang dipergunakan adalah:

a. Daya rencana 


$$
\begin{aligned}
& P d=f c \times P \\
& \text { Dimana : } \\
& \text { Pd : Daya rencana (W) } \\
& \text { fc : Koreksi daya } \\
& \text { P : Daya motor (W) }
\end{aligned}
$$

b. Torsi

$$
\begin{aligned}
& \mathrm{P}=\frac{2 \pi \mathrm{nT}}{60} \\
& \text { Sehingga, } \\
& \mathrm{T}=\frac{\mathrm{P} \times 60}{2 \pi \mathrm{n}} \\
& \text { Dimana : } \\
& \text { P : Daya motor (W) } \\
& \mathrm{n} \text { : Putaran silinder (rpm) } \\
& \mathrm{T} \text { : Torsi (Nm) }
\end{aligned}
$$

c. Tegangan geser yang diijinkan

$$
\tau_{\mathrm{gs}}=\frac{\sigma_{\mathrm{B}}}{\mathrm{Sf}_{1} \cdot \mathrm{Sf}_{2}}
$$

Dimana :

$\tau_{\text {gs }}:$ Tegangan geser yang diijinkan $\left(\mathrm{N} / \mathrm{mm}^{2}\right)$

$\sigma_{\mathrm{B}}:$ Kekuatan tarik $\left(\mathrm{N} / \mathrm{mm}^{2}\right)$

$\mathrm{Sf}_{1}$ : Faktor koreksi

$\mathrm{Sf}_{2}$ : Faktor koreksi

d. Diameter poros

$$
\begin{gathered}
\mathrm{T}=\frac{\pi}{16} \tau_{\mathrm{a}} \\
\text { Maka, } \\
\mathrm{d}=\sqrt[3]{\frac{16 \mathrm{~T}}{\pi \tau_{\mathrm{a}}}}
\end{gathered}
$$

Dimana :

D : Diameter poros (mm)

$\mathrm{T}$ : Momen puntir (Nmm)

$\tau_{\mathrm{a}}$ : Tegangan geser yang diijinkan $\left(\mathrm{N} / \mathrm{mm}^{2}\right)$

e. Tegangan geser

$$
\tau_{\mathrm{g}}=\frac{\mathrm{T}}{\frac{\pi \mathrm{d}_{\mathrm{s}} 3}{16}}=\frac{16 \mathrm{x} \mathrm{T}}{\pi \mathrm{d}_{\mathrm{s}} 3}
$$

Sehingga,

$$
\tau_{\mathrm{g}}=\frac{5,1 \times \mathrm{T}}{\mathrm{d}_{\mathrm{s}} 3}
$$

Dimana :

$$
\begin{array}{ll}
\tau_{\mathrm{g}} & : \text { Tegangan geser }\left(\mathrm{N} / \mathrm{mm}^{2}\right) \\
\mathrm{T} & : \text { Momen puntir }(\mathrm{Nmm}) \\
\mathrm{d}_{\mathrm{s}} & : \text { Diameter poros }(\mathrm{mm})
\end{array}
$$

\subsubsection{Pasak}

Pasak adalah suatu elemen yang dipakai untuk menetapkan bagian-bagian mesin seperti roda gigi, sproket, pully, kopling, dan lain-lain pada poros. Konstruksi pasak diberikan pada gambar 2.14 .

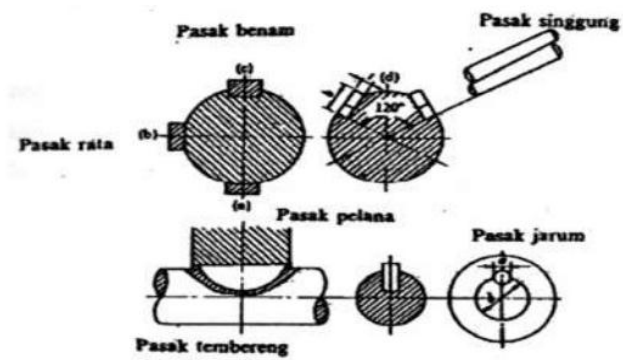

Gambar 2.14. Konstruksi Pasak

Rumus-rumus yang digunakan dalam perencanaan pasak adalah:

a. Gaya tangensial

$$
\mathrm{F}=\frac{\mathrm{T}}{\mathrm{ds} / 2}
$$

Dimana :

$\mathrm{F}$ : Gaya tangensial pasak (N)

$\mathrm{T}$ : Momen puntir dari poros $(\mathrm{Nmm})$

Ds : Diameter poros terkecil (mm)

b. Tegangan geser yang diijinkan

$$
\tau_{\mathrm{ka}}=\frac{\sigma_{\mathrm{B}}}{\mathrm{Sfk}_{1} \cdot \mathrm{Sfk}_{2}}
$$

Dimana :

$\tau_{\mathrm{ka}}$ : Tegangan geser pada pasak yang diijinkan $\left(\mathrm{N} / \mathrm{mm}^{2}\right)$

$\sigma_{\mathrm{B}} \quad:$ Kekuatan tarik $\left(\mathrm{N} / \mathrm{mm}^{2}\right)$

$\mathrm{Sfk}_{1} \quad$ : Faktor keamanan

$\mathrm{Sfk}_{2} \quad$ : Faktor keamanan

c. Lebar (w) dan tebal (t)

$$
\begin{aligned}
\mathrm{w} & =\frac{\mathrm{d}}{4} \\
\mathrm{t} & =\frac{2}{3} \mathrm{x} \mathrm{w}
\end{aligned}
$$

d. Panjang pasak (1)

Panjang pasak dapat diketahui berdasarkan torsi dan kekuatan tarik yaitu:

a. Berdasarkan torsi

$$
\mathrm{T}=1 . \mathrm{w} \cdot \tau_{\mathrm{a}} \cdot \frac{\mathrm{d}}{2}
$$

atau,

$$
\begin{aligned}
\mathrm{T}=\frac{\pi}{16} \cdot \tau_{\mathrm{a}} \cdot \mathrm{d}^{3} \\
\frac{\pi}{16} \cdot \tau_{\mathrm{a}} \cdot \mathrm{d}^{3}=1 \cdot \mathrm{w} \cdot \tau_{\mathrm{a}} \cdot \frac{\mathrm{d}}{2} \\
\frac{\pi}{16} \cdot \mathrm{d}^{3}=\frac{1 \cdot \mathrm{w}}{2}
\end{aligned}
$$

Sehingga, 


$$
1=\frac{\pi \cdot d^{2}}{8 w}
$$

b. Berdasarkan kekuatan tarik

$$
1=\frac{\pi \cdot \mathrm{x} \cdot \tau_{\mathrm{a}} \mathrm{xd}^{2}}{4 \mathrm{t} \times \sigma_{\mathrm{B}}}
$$

Dimana :

$\mathrm{T}$ : Torsi poros (Nmm)

d : Diameter poros $(\mathrm{mm})$

1 : Panjang pasak (mm)

\subsubsection{Bantalan}

Bantalan adalah elemen mesin yang menumpu poros berbeban, sehingga putaran atau gerakan bolak baliknya dapat berlangsung secara halus, aman, dan panjang umur. Bantalan harus cukup kokoh untuk memungkinkan poros serta elemen mesin lainnya bekerja dengan baik. Jadi, bantalan dalam permesinan dapat disamakan peranannya dengan pondasi pada gedung. Konstruksi bantalan dapat dilihat pada gambar 2.15 .

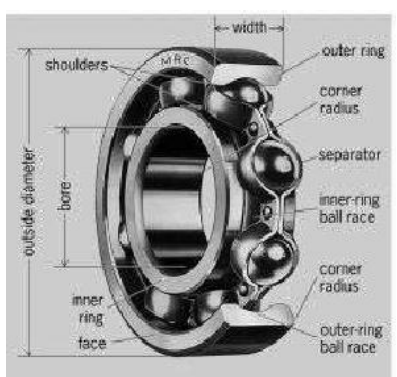

Gambar 2.15 Konstruksi Bantalan

Rumus-rumus yang digunakan dalam perancangan bantalan adalah :

a. Beban ekuivalen dinamis (Wb)

$\mathrm{Wb}=\mathrm{m} \times \mathrm{g}$

Dimana :

$\mathrm{Wb}$ : Beban ekuivalen $(\mathrm{N})$

$\mathrm{m}$ : Massa dari beban bantalan $(\mathrm{kg})$

$\mathrm{g}:$ Percepatan gravitasi $=9,81 \mathrm{~m} / \mathrm{s}^{2}$

b. Luas permukaan bantalan

$$
\mathrm{Ab}=\frac{\pi}{4} \mathrm{xdb^{2 }}
$$

Dimana :

$\mathrm{Ab} \quad$ : Luas permukaan bantalan $\left(\mathrm{mm}^{2}\right)$

$\mathrm{db} \quad$ : Diameter bantalan (mm)

c. Tegangan yang diterima bantalan

$\sigma_{\mathrm{b}}=\frac{\mathrm{F}}{\mathrm{Ab}}=\frac{\mathrm{Wb}}{\mathrm{Ab}}$

Dimana :

$\sigma_{\mathrm{b}}$ : Tegangan yang diterima bantalan $\left(\mathrm{N} / \mathrm{mm}^{2}\right)$

$\mathrm{Wb} \quad$ : Beban ekuivalen $(\mathrm{N})$

$\mathrm{Ab} \quad$ : Luas permukaan bantalan $\left(\mathrm{mm}^{2}\right)$ d. Tegangan yang diijinkan pada material bantalan

$\sigma_{\mathrm{Ab}}=\frac{\sigma_{\mathrm{u}}}{\mathrm{Sf}}$

Dimana :

$\sigma_{\mathrm{Ab}} \quad$ : Tegangan yang diijinkan pada material bantalan $\left(\mathrm{N} / \mathrm{mm}^{2}\right)$

$\sigma_{\mathrm{u}} \quad$ : Tegangan tarik $\left(\mathrm{N} / \mathrm{mm}^{2}\right)$

Sf : Faktor keamanan

\subsubsection{Dudukan Alat Perontok Jagung}

Rumus-rumus yang digunakan dalam perancangan dudukan alat perontok jagung adalah :

$\tau_{\mathrm{g}}=\frac{\mathrm{F}}{\mathrm{A}}$

Dimana :

$\tau_{\mathrm{g}} \quad$ : Tegangan geser $\left(\mathrm{kg} / \mathrm{mm}^{2}\right)$

$\mathrm{F} \quad$ : Gaya $(\mathrm{N})$

A : Luas permukaan $\left(\mathrm{mm}^{2}\right)$

\subsubsection{Motor}

Mesin perontok padi membutuhkan sumber daya penggerak yang menghasilkan gaya putar. Oleh sebab itu dipergunakan motor listrik sebagai sumber penggerak yang akan menghasilkan gerak putar pada silinder perontok.

Perencanaan daya motor :

$$
\mathrm{P}=\frac{2 \pi \cdot \mathrm{n} \cdot \mathrm{T}}{60}
$$

Dimana :

P : Daya (watt)

$\mathrm{T}:$ Torsi silinder $(\mathrm{Nmm})$

\section{METODOLOGI PENELITIAN}

Diagram alir pelaksanaan penelitian dapat dilihat seperti pada gambar 3.1.

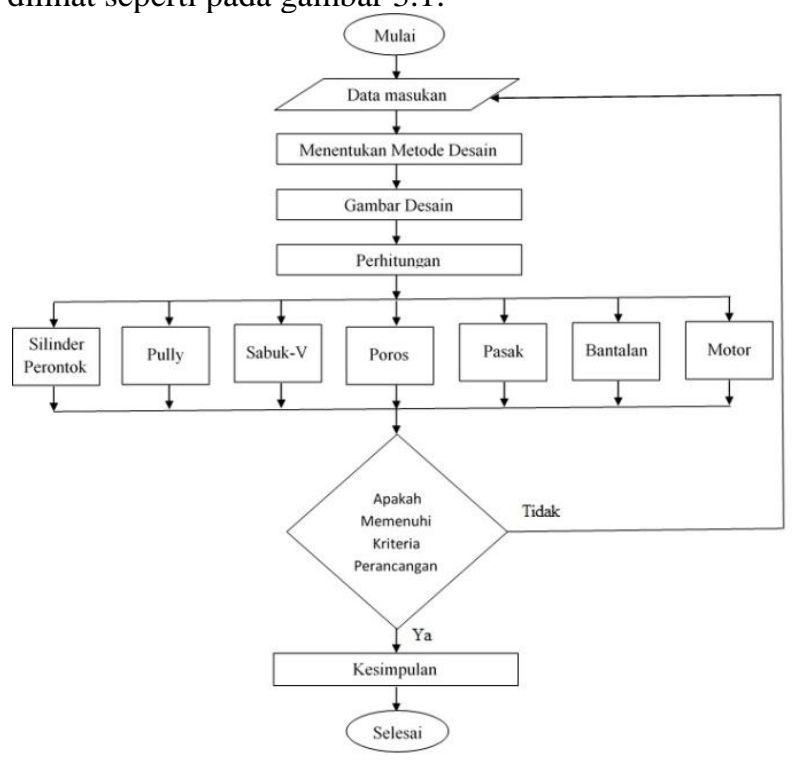

Gambar 3.1. Diagram alir proses perancangan mesin perontok jagung 
Keterangan :

1. Data Masukan, yaitu merencanakan langkah dan tujuan dari perancangan mesin perontok jagung.

2. Studi lapangan, yaitu melakukan pengamatan dikeadaan sekitar atau kebutuhan pasar.

3. Studi Pustaka, yaitu melakukan pengamatan melalui media tertulis untuk membantu studi lapangan.

4. Menentukan metode desain, yaitu melakukan ide-ide yang dibahas mengenai perancangan mesin perontok jagung.

5. Gambar desain, yaitu suatu gambaran dari perancangan suatu mesin.

6. Perhitungan Pully, V-belt, Silinder Perontok, Motor Listrik, Poros, Pasak, Bantalan yaitu rumus dasar yang digunakan untuk perancangan mesin perontok jagung.

7. Apakah memenuhi kriteria perancangan, yaitu suatu keputusan dari proses perancangan mesin perontok jagung, apabila tidak memenuhi kriteria akan kembali ke data masukan, apabila memenuhi kriteria perancangan mesin perontok jagung maka akan ke proses selanjutnya.

8. Kesimpulan, yaitu menyimpulkan dari hasil analisa perancangan mesin perontok jagung yang didapatkan selama penelitian.

\section{ANALISA HASIL}

Setelah dilakukan analisa perhitungan pada setiap komponen pendukung perancangan mesin perontok jagung, maka didapatkan hasil yang menjadi dasar dalam perancangan mesin perontok jagung, yaitu :

\subsection{Silinder Perontok}

Silinder perontok terbuat dari besi plat strip dengan tebal $6 \mathrm{~mm}$, panjang $900 \mathrm{~mm}$, dan plat besi silinder berdiameter $430 \mathrm{~mm}$ dengan tebal $5 \mathrm{~mm}$. Dari perhitungan didapat momen inersia sebesar $0,1746\left(\mathrm{Nm}^{2}\right)$ dan torsi 7,3 $(\mathrm{Nm})$.

\subsection{Pully}

Diameter pully penggerak yang digunakan sebesar $75 \mathrm{~mm}$ dengan putaran motor $\left(\mathrm{n}_{1}\right) 1500$ rpm, putaran pully yang digerakkan diinginkan 315 rpm. Dari hasil perhitungan diameter pully yang digerakkan didapat 357,1 mm. Dengan demikian dimensi kedua pully memenuhi syarat.

\subsection{V-belt}

V-belt yang digunakkan adalah sabuk tipe A-5 dengan spesifikasi : lebar (w) $=9 \mathrm{~mm}$, tebal $(\mathrm{t})=6 \mathrm{~mm}$ dan panjang sabuk $(\mathrm{L})=$ $2135 \mathrm{~mm}$. Kecepatan liniernya $(\mathrm{v})=6(\mathrm{~m} / \mathrm{s})$. Jarak antara poros motor dengan poros silinder adalah $714,2 \mathrm{~mm}$, sehingga panjang sabuk memenuhi syarat.

\subsection{Poros}

Poros terbuat dari bahan baja S45C dengan kekuatan tarik sebesar 568,98 N/mm² dan faktor keamanan diambil 5. Diameter poros hasil perhitungan diperoleh $8,34 \mathrm{~mm}$, tetapi dalam perakitannya digunakan poros berdiameter $45 \mathrm{~mm}$. Tegangan geser untuk diameter $45 \mathrm{~mm}$ sebesar 0,36 $\mathrm{N} / \mathrm{mm}^{2}$ dan tegangan geser yang diijinkan sebesar $56,90 \mathrm{~N} / \mathrm{mm}^{2}$. Oleh karena $\tau_{\mathrm{g}}\left(0,36 \mathrm{~N} / \mathrm{mm}^{2}\right)<\tau_{\mathrm{gs}}($ $56,90 \mathrm{~N} / \mathrm{mm}^{2}$ ) maka perencanaan poros aman.

\subsection{Pasak}

Bahan yang digunakan untuk pasak adalah baja S45C mempunyai kekuatan Tarik sebesar $568,98 \mathrm{~N} / \mathrm{mm}^{2}$. Dari hasil perhitungan didapatkan pasak dengan ukuran penampang lebar $(\mathrm{w})=9$ $(\mathrm{mm})$, tebal $(\mathrm{t})=6(\mathrm{~mm})$, panjang $(\mathrm{l})=53,42 \mathrm{~mm}$. Tegangan geser yang diijinkan adalah $\left(\tau_{\mathrm{ka}}\right)=$ $56,898\left(\mathrm{~N} / \mathrm{mm}^{2}\right)>$ Tegangan geser yang terjadi sebesar $\tau_{\mathrm{g}}=0,1262\left(\mathrm{~N} / \mathrm{mm}^{2}\right)$ maka perencanaan poros aman.

\subsection{Bantalan}

Jenis bantalan yang digunakan adalah bantalan gelinding, karena gesekan yang terjadi relatif rendah dan pelumasannya sangat sederhana. Diameter luar sebesar $45 \mathrm{~mm}$ dan diameter dalam $35 \mathrm{~mm}$. Dari hasil perhitungan didapatkan :

- Gaya berat poros $\mathrm{Wp}=270,02(\mathrm{~N})$

- Beban ekuivalen dinamis $(\mathrm{Wb})=662,175$ (N)

- Luas permukaan bantalan $(\mathrm{Ab})=961,6$ $\left(\mathrm{mm}^{2}\right)$

- Tegangan yang diterima $\left(\sigma_{\mathrm{b}}\right)=0,689$ $\left(\mathrm{N} / \mathrm{mm}^{2}\right)$

- Tegangan yang diijinkan $\left(\sigma_{\mathrm{Ab}}\right)=58,90$ $\left(\mathrm{N} / \mathrm{mm}^{2}\right)$

Oleh karena $\sigma_{\mathrm{b}}<\sigma_{\mathrm{ab}}$ maka perencanaan bantalan memenuhi syarat.

- Faktor kecepatan $(\mathrm{Fn})=0,47(\mathrm{~m} / \mathrm{s})$

- Faktor umur $(\mathrm{Fh})=373$

- Umur nominal (Lh) = 259475585 Jam

\subsection{Motor}

Daya motor yang diperlukan untuk menggerakkan silinder perontok adalah sebesar 164,3 (W), sedangkan daya terpasang sebesar 213,6 (W). Oleh karena itu $\mathrm{P}_{\text {rencana }}<\mathrm{P}_{\text {terpasang maka }}$ perencanaan motor memenuhi syarat.

\section{KESIMPULAN DAN SARAN \\ 5.1 Kesimpulan}

Berdasarkan hasil analisa dan pembahasan perancangan mesin perontok jagung dengan 
kapasitas produksi $300 \mathrm{~kg} / \mathrm{jam}$, maka dapat diambil kesimpulan sebagai berikut:

1. Silinder perontok jagung terbuat dari besi plat strip dengan tebal $6 \mathrm{~mm}$, panjang 900 $\mathrm{mm}$, dan plat besi silinder berdiameter 430 mm dengan tebal $5 \mathrm{~mm}$.

2. Sistem transmisi yang digunakan adalah pully, v-belt dan bantalan. Pully yang digunakan ada 2 buah, pully ke- 1 (penggerak) berukuran $75 \mathrm{~mm}$ dengan putaran motor $\left(\mathrm{n}_{1}\right)$ sebesar $1500 \mathrm{rpm}$, sedangkan pada pully ke-2 (digerakkan) berukuran $357,1 \mathrm{~mm}$ dengan putaran motor $\left(\mathrm{n}_{2}\right)$ sebesar $315 \mathrm{rpm}$. V-belt yang digunakan adalah $v$-belt A-5 dengan lebar $(\mathrm{w})=9 \mathrm{~mm}$, tebal $(\mathrm{t})=6 \mathrm{~mm}$ dan panjang $v$-belt $(\mathrm{L})=$ $2135 \mathrm{~mm}$ dengan kecepatan liniernya $(\mathrm{v})=6$ $(\mathrm{m} / \mathrm{s})$. Jarak antara poros motor dengan poros silinder adalah $714,2 \mathrm{~mm}$ dengan kecepatan silinder perontok sebesar 315 rpm. Sedangkan jenis bantalan yang digunakan adalah bantalan gelinding, karena gesekan yang terjadi rendah dan pelumasan yang sederhana dengan luas permukaan bantalan (Ab) 961,6 $\mathrm{mm}^{2}$. Maka tegangan yang diijinkan $(\sigma \mathrm{Ab})=58,90 \mathrm{~N} / \mathrm{mm}^{2}>$ tegangan yang terjadi $(\sigma b)=0,689\left(\mathrm{~N} / \mathrm{mm}^{2}\right)$. Diameter luar bantalan sebesar $45 \mathrm{~mm}$ dan diameter dalam $35 \mathrm{~mm}$. Dari hasil perhitungan didapatkan :

- Gaya berat poros $\mathrm{Wp}=270,02(\mathrm{~N})$

- Beban ekuivalen dinamis $(\mathrm{Wb})=$ $662,175(\mathrm{~N})$

- Luas permukaan bantalan $(\mathrm{Ab})=961,6$ $\left(\mathrm{mm}^{2}\right)$

- Tegangan yang diterima $(\sigma \mathrm{b})=0,689$ $\left(\mathrm{N} / \mathrm{mm}^{2}\right)$

- Tegangan yang diijinkan $(\sigma \mathrm{Ab})=58,90$ $\left(\mathrm{N} / \mathrm{mm}^{2}\right)$

- Faktor kecepatan $(\mathrm{Fn})=0,47(\mathrm{~m} / \mathrm{s})$

- Faktor umur (Fh) = 373

- Umur nominal (Lh) = 259475585jam

3. Poros yang digunakan dari bahan baja S45C dengan kekuatan tarik sebesar 568,98 $\mathrm{N} / \mathrm{mm}^{2}$ dan faktor keamanan diambil 5, diameter poros $8,34 \mathrm{~mm}$ dengan tegangan geser sebesar $0,36 \mathrm{~N} / \mathrm{mm}^{2}$ dan tegangan geser yang diijinkan sebesar 56,90 N/mm², sedangkan pasak dengan lebar $(\mathrm{w})=9$ $(\mathrm{mm})$, tebal $(\mathrm{t})=6(\mathrm{~mm})$, panjang $(\mathrm{l})=$ $53,42 \mathrm{~mm}$ dengan tegangan geser yang diijinkan sebesar $56,898 \mathrm{~N} / \mathrm{mm}^{2}$ dan tegangan geser yang terjadi sebesar 0,1262 $\mathrm{N} / \mathrm{mm}^{2}$.

4. Daya motor listrik yang diperlukan untuk menggerakkan silinder perontok sebesar $164,3(\mathrm{~W})$, sedangkan daya yang terpasang sebesar 213,6 (W).

\subsection{Saran}

Sebagai saran yang dapat disampaikan berdasarkan pada hasil perancangan mesin perontok jagung sebagai berikut :

1. Untuk mendapatkan hasil yang maksimal perancangan suatu mesin harus dilakukan secara berurutan.

2. Untuk mengoptimalkan fungsi alat ini perlu diperhatikan bahwa jagung yang akan dirontok dari bonggolnya harus dalam keadaan kering.

\section{DAFTAR PUSTAKA}

1. Achyanto, Djoko, Ir. 1997. Mesin-Mesin Listrik . Edisi terjemahan. Jakarta: Penerbit Erlangga.

2. Candra, A \& Wardiyanto 2011. The Construction Design Of Corn Sheller and Corncob Crusher Machine. Tugas Ahir tidak diterbitkan. Surabaya: FTIITS.

3. Oktoviantini Hadi, V. 2010. Analisis kelayakan ekonomi agroindustri emping jagung dalam rangka pengembangan usaha. Universitas Brawijaya fakultas pertanian Program Studi sosial ekonomi pertanian program studi agribisnis malang.

4. Sonawan, Hery, Ir. 2010. Perancangan Elemen Mesin. Bandung : Penerbit Alfabeta.

5. Sovan, Muhaimin. 2003. Biologi Jagung. Jakarta: Wikipedia Indonesia

6. Stolk, J. ir, dan Kros, C. ir. 1994. Elemen Mesin Elemen Konstruksi Bangunan Mesin. Jakarta: Penerbit Erlangga

7. Stolk and Kros, C. 1994. Konstruksi Bangun Mesin. Jakarta: Erlangga.

8. Sularso dan Suga, Kiyokatsu. 2004. Dasar Perencanaan dan Pemilihan Elemen Mesin. Jakarta :Penerbit PT. Pradnya Paramita.

9. Purdianto. 2014. Perencanaan Mesin Perajang bonggol Sebagai Bahan Dasar Pembuatan plastic Biodegradble

10. Khurmi, R. S., Gupta, J. K. 1982. Machine Design. New Dehli. 